\section{A Case of $\mathbf{Q}$ Fever}

The following case of $Q$ fever may be found of interest. The source of infection is unknown, and is being investigated. So far as can be ascertained, no previously recognized casss have occurred in the same area.

\section{Case Report}

The patient was a retired Indian, cavalry officer aged 58, with a good medical history. Apart from dengue fever in 1913 , and malnutrition while a prisoner of war in Bulgaria in 1918, he has always enjoyed good health. The present illness began on the evening of April 25, 1950, with general muscular aching. During the night he had a rigor and a very heavy sweat. When seen next morning his temperature was $100.3^{\circ}$ F. $\left(37.95^{\circ}\right.$ C.) and pulse 88 . On examination some injection of his pharynx was found, but otherwise physical examination was negative. The heart souncs were pure and closed; blood pressure was $140 / 80$; the lungs were clear. He complained of muscular aching in his limbs, and said that he felt bruised all over. Influenza was diagnosed, it being epidemic in the area, and he was treated accordingly.

When next seen, on April 28, the picture had changed considerably. His temperature had remained up, swinging between 101 and $103.5^{\circ}$ F. $\left(38.3\right.$ and $39.75^{\circ}$ C.) ; he had had some very heavy sweats and a rigor during the previous night. He still complained of much pain in his musculature and had devcloped a slight cough. On examination his temperature was $102^{\circ} \mathrm{F}$. $\left(38.9^{\circ} \mathrm{C}\right.$.), pulse 88 , and respirations 30. He was markedly dyspnoeic and cyanosed, with a dusky flushed face. There were scattered rales and rhonchi all over both lungs. As he was obviously pneumonic full doses of "sulphatriad" were given, together with 200,000 units of crystalline penicillin in the morning and 300,000 units of "distaquaine" penicillin at night.

During the next two days his condition remained unchanged. He was cyanosed and dyspnoeic, with fever swinging between 101 and $102.5^{\circ} \mathrm{F}$. (38.3 and $39.15^{\circ} \mathrm{C}$.), and with a pulse rate of 80 to 90 . His muscular aching was troublesome, but cough was not a striking feature. His physical signs remained unchanged.

By the morning of May 1 he had developed signs of consolidation in his right upper lobe, with impairment and faint bronchial breathing best heard in the axilla. His general condition remained unchanged, and he did not give cause for anxiety. There was no sign of response to the sulphonamides and penicillin, and it was thought probable, therefore, that he had an atypical virus pneumonia. An $x$-ray film of the chest showed a consolidation of the right upper lobe spreading outwards from the root, the remainder of the lung fields being clear. A blood count made by Dr. Lazarus Barlow showed: haemoglobin, 16 g. \% (100\% Sahli); red oells, 4,900,000 per c.mm.; C.I., 1.0 ; leucocytes, 2,800 per c.mm. (polymorphs $66 \%$, monocytes $5 \%$, lymphocytes $29 \%$ ). Ccid agglutinins were present at $1 / 80$.

In view of the $x$-ray appearances, the leucopenia, and the presence of cold agglutinins, the diagnosis of atypical virus pneumonia was thought to be correct. The sulphatriad was therefore stopped and the patient was kept under penicillin guard.

During the next day violent shooting pains in the face, head, and limbs developed. These were quite transitory but severe, and were accompanied by violent twitching in the muscles. Those in the face were reminiscent of a tic douloureux; those in the limbs produced a jerk sufficient to disarray the bedclothes. They led to much disturbance of sleep, but were not associated with any positive physical findings in the C.N.S.

On May 3 the patient was seen in consultation with Dr. J. M. Ranking, of Tunbridge Wells. His condition was unchanged except that he appeared to be developing a macular rash, which was then visible only on his back.
Dr. Ranking agreed with the provisional diagnosis, but suggested that the possibility of $Q$ fever should be considered. This had already been discussed with Dr. Barlow, who had kept some of the patient's serum in case further investigations should be required. Dr. Barlow was accordingly asked to forward this serum to the Virus Reference Laboratory at Colinda!e. Dr. Ranking obtained some "aureomycin," and treatment with this was begun at midday-two capsules six-hourly.

By the morning of May 4 there had been a most dramatic response to the aureomycin. The temperature was normal and the pulse rate 72 . The patient looked and felt much better ; the muscular pains and twitching had vanished overnight. He was, however, covered with a macular rash, dusky red in colour, most pronounced on the back, where it had first appeared, but also prominent on the front of the trunk and the limbs. The face was not involved. For the first time his spleen "was easily palpable. He was no longer cyanosed, there were signs of resolution over the chest lesion, and his urine showed a trace of albumin only, red blood cells not being present.

Thereafter his improvement was steady and rapid. The aureomycin was continued until his temperature had been normal for four days. By May 16 his rash had gone, his spleen was no longer palpable, his chest was clear, and he was eating and sleeping well. He has remained well since.

The following additional investigations were carried out: Paul-Bunnell test: negative at $1 / 10$. A blood culture showed no growth after seven days. The Widal test showed agglutination to a dilution of 1/120 in Salmonella typhi $\mathrm{H}$ only; no agglutination in the remainder of the typhoid, paratyphoid, or abortus group. Sputum: tubercle bacilli were not found; cultivation yielded a scanty growth of non-haemolytic streptococci. Faeces: no pathogenic organisms cultivated. Complement-fixation tests carried out by Dr. B. P. Marmion at the Virus Reference Laboratory, Colindale, showed:

\begin{tabular}{|c|c|c|c|c|c|}
\hline \multirow{3}{*}{$\begin{array}{l}\text { Day of } \\
\text { Disease }\end{array}$} & \multicolumn{4}{|c|}{ Complement-fixation Tests } & \multirow{3}{*}{$\begin{array}{c}\begin{array}{c}\text { Agglutina- } \\
\text { tion }\end{array} \\
\begin{array}{c}\text { Strepto- } \\
\text { coccus } \\
\text { M.G. }\end{array}\end{array}$} \\
\hline & \multicolumn{2}{|c|}{ Influenza } & \multirow{2}{*}{$\begin{array}{c}Q \\
\text { Fever }\end{array}$} & \multirow{2}{*}{$\begin{array}{l}\text { Psitta- } \\
\text { cosis } \\
\text { L.G.V.* }\end{array}$} & \\
\hline & Sol. A & Sol. B & & & \\
\hline $\begin{array}{ll}10 & \ldots \\
14 & \\
5 & \text { weeks }\end{array}$ & $\begin{array}{c}<1 / 4 \\
<1 / 4 \\
\text { Not tested }\end{array}$ & $\begin{array}{c}<1 / 4 \\
<1 / 4 \\
\text { Not tested }\end{array}$ & $\begin{array}{l}<1 / 8 \\
<1 / 16 \\
<1 / 256\end{array}$ & $\begin{array}{c}<1 / 8 \\
<1 / 8 \\
\text { Not tested }\end{array}$ & $\begin{array}{c}<1 / 10 \\
<1 / 10 \\
\text { Not tested }\end{array}$ \\
\hline
\end{tabular}

* The psittacosis-lymphogranuloma venereum group of viruses.

This man's illness, therefore, was certainly due to infection with Rickettsia burneti. The striking features of this illness were the pneumonia, which gave rise to some anxiety, the rash, the enlarged spleen, and the signs of involvement of the C.N.S. It was worthy of note that throughout the illness his pulse rate was never as rapid as one would have expected from the degree of fever. A most encouraging result 'was obtained from the use of aureomycin, the illness literally being cut short and all anxiety enced within 36 hours.

I am greatly indebted to Drs. Barlow and Marmion for the investigations they carried out in this case, to Dr. W. Addey for the $x$-ray films, and to Dr. Ranking for his advice and his help in obtaining the aureomycin.

\section{H. Cameron, M.R.C.S., L.R.C.P.}

At present there are no schools for mentally handicapped children in the Isle of Man, and the question of providing accommodation for them on the island is shortly to be discussed (School Medical Officer's Report, 1950). The dental department is now up to full establishment, and there are four full-time dental officers-one temporarily for six months. During the year 2,517 medical examinations were carried out, and $15 \%$ of the children needed treatment. Schoolchildren on the island are drinking about 800 pints of milk a day, and nearly half of this amount is supplied free. 